\title{
水化物の眖水と造粒の同時操作についで
}

\author{
吉田 哲 夫**·戸田浩 次*** \\ 山 崎 尉 二*** \\ 大阪市立大学 工学部
}

\section{楮 言}

回転を用いた造粒にみられる従来の研究は，战すに畭 蜗した粉体を原料とし，これに水，または溶液を添加し て行なう造粒操作に関するるので，回分式ドラム造粒に ついては Newitt ${ }^{13}$ ，皿型造粒については河野2)などの 報告がある。

本報で述へるすのは，原料として結晶水をすつ水化物 を使用し，これに加熱操作を加え，そのさい融出する結 晶水を結合媒体として造粒を行なうるのであり，しかむ 加熱のさいの結晶水の融出，ならぴに融出水分の蒸発の 各過程が段階的に進行するので，造粒，ならびに造粒物 の乾燥の両操作を一つの装直で連続的行行なって，その さいの操作条件，ならびにそれら条件の造粒物に拈よば す埧箬を考察したものである。

\section{1. 実験装㥀およひ供給原料}

装䈯の概要は Fig. 1に示すように，固定式スクレー パーを内藏した内径 $300 \mathrm{~mm} \phi$, 加熱部妒長 $1650 \mathrm{~mm}$ の 鉄製ドラムに，然焼ガスの流れと供給原料の流れとが向 流になるように然焼室を配置した間接加熱方式のロータ リー型の炬で，ドラムの回転はチェン駆動により 6 30 $\mathrm{rpm}$ の变速を可能とし，ドラムの傾斜は装瞋全体を組 み込んだ架台の一方を上下することによって自由に変化 させらるよらにしたものである。

原料供給は、スクリューフィーダーで定量的に行なわ れる。なお造粒物排出側のドラムの末端に蒸気抜きの排 気筒を設けている。

供給原料は Table 1 に示すように，水化物に，シー ドとしてその水化物の脱水物を配合したあので，このシ 一ドは，本装直の運転により製

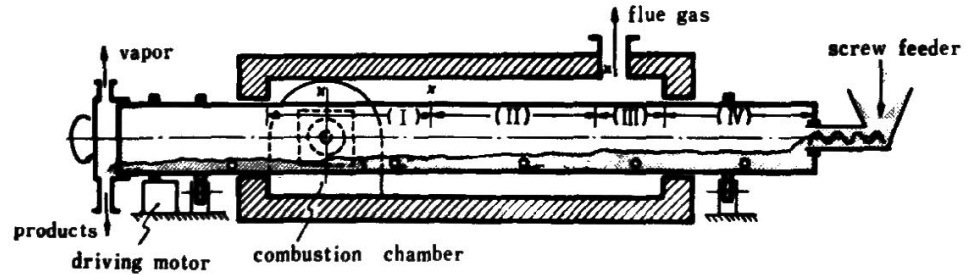

(I) drying zone

(II) granulating zone

(III) sticky zone
(V) mixing and wetting zone
C. $x$ temperature measuring point 造された造粒物中, 所望の粒径 外のものを箱分けし，さらにこ れを 25 mesh節で通過する程度 に、粉碎したすのである。 また本実験において得られた 造粒物粒度は, $2 \mathrm{~mm} \phi$ 以下 31 $\%, 2 \sim 5 \mathrm{~mm} \phi 42 \%, 5 \mathrm{~mm} \phi$ 以 上 $27 \%$ 程度のるのであった。

Fig. 1 Experimental apparatus

Table 1 Properties of material and seed

$\begin{array}{llll} & \text { Material } & \text { seed } \\ \text { Density } & \begin{array}{l}\text { true } \\ \text { apparent }\left[\mathrm{gr} / \mathrm{cm}^{3}\right]\end{array} & 1.90 & 3.05 \\ \begin{array}{l}\text { Water of crystallization to be } \\ \text { melted out by heat [\%] }\end{array} & 1.00 & 1.40 \\ \begin{array}{l}\text { Particle size } \\ \text { [\%] }\end{array} & 39.0 & 0 \\ \end{array}$

- <Simultaneous Dehydrating and Granulating Operation for a Hydrated Material>

Received on November 17,1965

昭和 40 年 10 月 (化学工学) 周山大会沪て研究発表

** Tetsuo Yoshida (Osaka City Univ., Faculty of Engineer ing, Osaka, Japan)

*** Kõji Toda and Jöji Yamasaki (户田工莱(怢) Toda Indus tries, Co. Ltd., Hiroshima )

\section{2. 実蚵桔果の考察}

\section{$2 \cdot 1$ 带城の形成}

定常運転にあるとき，ドラム内の原料は，ドラム軸方 向に沿った温度分布に応じて，それぞれ含有水分を異に した带域を形成することが観察された。

それら帯域を，それぞれ，混合湿潤帯，付着帯，造粒 成脣帯，乾嬠带と名つけままた付着帯と造粒成長帯とを 併せて，造粒帯とした。

i）湿合湿渵帶 この带域は，加熱室の外に形成 され，ドラムの回転に伴い，この带域では原料の混合， 拈よび予熱が行なわれる。一方，ドラム内の蒸気の一部 がこの带域で凝縮し，そのため，原料は湿潤状態になり ドラムへの付着が起こる。 
ii）付着帯 この帯域では, 結晶水の一部が融出 し, その充填構造は pendular funicular-I 程度まで進 行するすのと思われる。原料のドラムへの付着は激し く，一部はドラムの底を転動するが，その多くはドラム に付着し，回転に伴い，自重により，またスクレーパー によって滝状に落下する。この状態は造粒物成長の核の 生成に重要な役割を果しているものと考えられる。

iii）造粒成長帯 この带域では, 結晶水はすべて 融出を終り，核を中心に成長が始まる。

この帯域での充填構造は, funicular-I II の領城に ある。この帯域では原料のドラムへの付着は汪とんど認 められない。

iv）乾燥帯この帯域では，造粒物の成長はとま り, 造粒物の乾燥が進む。

なお，各帯域での原料保有率は，混合湿潤帯をビーク に逐次減少し, 造粒成長帯の末端に至り一定の率に落ち 着く。これは, 各帯域での原料の物理的変化に伴い，原料 の移動速度が变化することに起因するすのと思われる。

一方, 付着帯付近での原料のドラムへの付着は, 粉体 集合体表面の水分の影暨によるもので，粉体集合体表面 への水分の浸出速度>蒸発速度にあるとき付着が起こ

り，その逆の関係に打いては付着は起こらない。

付着防止のため, 付着带付近にバーナーを入れ急激な 加熱をするそ, 浸出速度く蒸発速度となり, 付着はない が炬内が激しく発鹿し，造粒現象が生じない。

したがって,この種の造粒において, 然焼室の位置 は，造粒操作上の重要な要素の一つと考えられる。

\section{$2 \cdot 2$ 造粒㩧作の条件}

本装眉の操業に批る変動可能な要因について，それ ぞれの要因が造粒に及ぼす影響を考察した。

すなわち

（a）シードの粉体としての特性, ならびにシードと ， 水化物との配合割合。

(b) ドラムの回転数, ドラム傾斜, および原料保有 率。

（c）伝熱ならびに原料供給速度。

i） シードの粉体としての特性 粉体特性を異に したシードを，以下に述へる操作によってつくり，シー ドの粉体特性の差巽が造粒に及に゙す影䈉を考察した。

本装置の操業で得た乾燥造粒物を粉碎し， 25 mesh 節 を通過させたものを第一回目のシードとし，その後は産 出する乾燥造粒物中 25 mesh 節を通過するすのをその ままシードとして，循環使用すると，そのシードの粉体 特性注循環度数に応じて变化した。それら粉体特性を見 虾比重で代表し，その相関を点綴すると Fig. 2 のこと くなった。これら見基比重の異なったシードによる造粒 の結果は、シードの見郝比重の減少につれ，でさた造粒 物の空隌率は增大し，その強度の減少傾向がみられた。

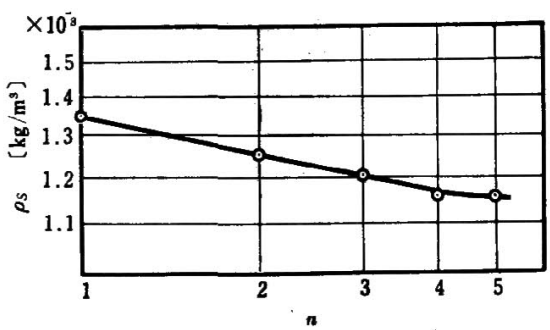

Fig. 2 Relation between apparent specific gravity of seed $\rho_{s}$ and reflux number $n$

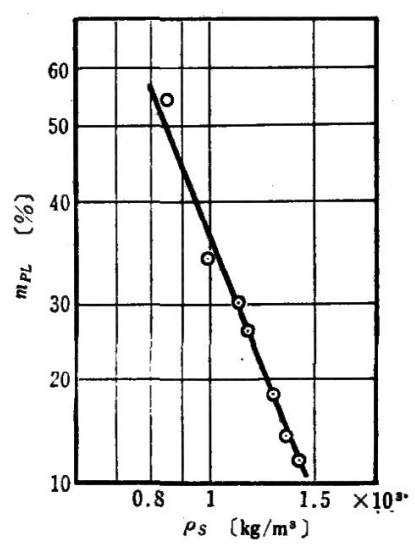

Fig. 3 Relation between apparent specific gravity of seed $\rho_{s}$ and moisture content alt plastic limit $m_{P L}$

一方, 見掛比重の減少につれて, 配合する水化物の割 合を增加しないと，造粒操作において水分不足の様相を 呈した。すなわち、シードの見比重の差異によって， 造粒水分に変動のあることが推定された。

ちなみに，見掛比重と可塑限界水分（JIS-A 1208）と の相関を点緅してみると Fig. 3 に示すように，見掛比 重の減少につれて, 可塑限界水分の大幅な增加がみられ る。

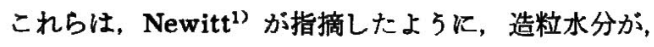
粉体特性によって変化する充填構造と, その空隌との間 に，密接な関係のあることを示している。

ii）供給原料の調製 一乾燥粉体に水を添加して行 な5造粒操作に批いて、河野2) は，造粒水分を造粒能水 分係数 $f_{g}$ で整理し, 各種粉体について, $f_{g}=0.75 \sim 0.82$ の範囲であるとし, 空気-水一粉体の充填構造からみて, funicular I III領域と考察している。すなわち

$$
f_{g}=\frac{\text { 造粒水分 }\left(m_{f}\right)}{\text { 可塑限界水分 }\left(m_{P L}\right)}=0.75 \sim 0.82
$$

本実験に括いて，水化物の配合割合 $x$ を变化させて实 験を行ない，造粒か门滑に行なわれた場合の $x$ を，以下 に示す式により， $f_{\theta}$ で整理してみると， $f_{0}=0.75 \sim 0.90$ となり，河野の結果とは注一致した。 


$$
\begin{aligned}
m_{f}=m_{P L} \cdot f_{g} & =\frac{\text { 融出結晶水重量 }}{\text { 全帨水物重量 }} \\
& =\frac{x \cdot n \mathrm{H}_{2} \mathrm{O} / M_{v}}{(1-x)+M_{0} x / M_{v}}
\end{aligned}
$$

水化物分子量 $\left(\boldsymbol{M}_{w}\right)$-脱水物分子量 $\left(\boldsymbol{M}_{0}\right)$

$=$ 㮹出結晶水 $\left(\mathrm{nH}_{2} \mathrm{O}\right)$

これらの関係式を整理すると，次式のよ5になる。

$$
f_{0}=\frac{x \cdot n \mathrm{H}_{2} \mathrm{O}}{m_{P L}\left(M_{v}-x \cdot n \mathrm{H}_{2} \mathrm{O}\right)}
$$

$f_{0}$ が $0.75 \sim 0.90$ の籍围外の配合で造粒操作を行なる そ次に述へるような操作上の問題が発生した。

$f_{0}<0.75$ の場合，造粒成長帯は水分が不足し，非常 にボーラスな塊と，塊の破壊に上る微粉が生成する。

極端に $f_{0}$ を小さくすると，造粒は全く起こらず，妒 内に激しい発鹿が起こる。

一方， $f_{0}>0.90$ の場合，造粒成長带でいったんでき た造粒物が互にくっつき合って集団化し，これが一団と なって，ドラム円周方向の滑りを起こし，遂には造粒成 長带の原料は带状につながる。これが晞嬠帯でちきれ大 きな塊を排出するようになる。

$f_{\sigma}$ を極端に大きくすると，付着带付近で原料はドロ ドロに溶骶し，これがスクレーパー上に付着堆積してス ケールを形成し，これが次第に成長して操業不能に陥 る。

iii） ドラムの回転数 ドラム内の原料粒子の運動 は回転速度, ならびに原料の物理的性状によって異な る。

今造粒成長带に着目して，回転数に応じ原料の運動 状態を製察すると，回枟のおそい間は，ドラム壁に沿っ て持ち上げられた原料の一部が原料層表面上を，周期的 に，なだれ状に滑る状態がみられるが，回転数の增加に つれて，なだれの部分は炊第に減少し，遂には粒子が連 絰的に原料層表面を転動するよろになる。更に回転をあ げると，原料は、ドラムの中心に引いた水平面以上に持 ち上げられ， cascading の状態に達する。

造粒操作は，原料の運動が転動状態にあるとき円滑に 行なかれた。この状態におけるドラムの回転数は、湢界 回転数の約 $32 \%$ 程度であった。

Newitt ${ }^{12}$ は，その実検に括いて，臨界回転数の 37\% が造粒に望ましく，その運動状態を cascading にしな いよらに注意している。

iv）傎斜，および保有率 一定量の原料供給下で， ドラムの倾斜を变化させると，保有事に变動がみられ る。㑯斜を大きくしすきると，造粒物の粒径江減少し， かつ造粒成長带で，比校的粒径の大きい造粒物が，ドラ ム軸方向の滑りを起こし，末㖕煤のままで排出する傾向 がでてくる。

逆に㑯斜を小さくしすきると，保有率俚增大し，造粒 成長带で，しばしば造粒物が集合化する傾向があらわれ
る。また本実跧においては，混合湿潤帯の保有率が異常 に增加するため，ドラムと原料供給口との間にある隙間 から，原料の滑流出を起こした。

以上のようK，造粒操作の面から，造粒成長帯に批 る保有率は，4\% 程度が適当であると判断した。

Newitt ${ }^{12}$ は，造粒物の粒子成長速度の見地から保有 率を考察し，5６\% が適正であると報告している。

v）滞留時間 一般に，この種のキルンの滞留時 間 $\theta$ は次式によって示される。

$$
\begin{aligned}
& \theta=k L / N D S \\
& \theta=60 \mathrm{~V} \rho X / 100 Q_{w}
\end{aligned}
$$

$L$ は妒長， $N$ はドラム回転数，Dはドラム直径， $S$ は ドラム傾斜，Vはドラム容積， $\rho$ は原料見卦比重，Xは 原料保有虫，Qw

一方 Newitt” の報告している

$$
D_{p} \propto N \theta_{(a)}
$$

なる実験結果を用いて，Eq.(5)を書きかえれば，ドラ ム径が一定のときには

$$
D_{p} \propto L_{(G)} / S
$$

が得られる。この上ろな関係は本装直の運転においてい 定性的港められた。

また，Eq.(7) の関係は，ドラム回転数 $N$ が造粒操 作の面から，そのドラムの直径D応じて一定值に規制 されるところから，造粒物の粒径は，その滞留時間 $\theta_{(G)}$ に応じて決められることを意味すると考えられる。

そこで，前述の造粒操作から规制される $X_{\text {opt }}$ ，およ

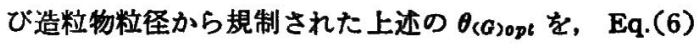
に代入整理すると,

$$
\frac{Q_{w}}{V(G)}=\frac{60}{100} \cdot \frac{\rho X_{\text {opt }}}{\theta_{(G) \text { opt }}}=K_{\text {opt }}
$$

となり，Eq.(9)より，本装貫の操業において，造粒物 の所定の粒径に対し，造粒帯の単位容猜当たりの原料供 給速度か， $K_{\text {opt }}$ から定まることがわかる。一方， $V_{(G)}=$ $\pi D^{2} L(a) / 4$ であるところから, Eq.(9) より

$$
L_{(G)}=4 Q_{w} / \pi D^{2} K_{\text {opt }}
$$

の関係が成立する。

vi）文 熱 基本的には，供給原料に対し，その 結晶水の融出，および蒸発に必要な熱量を与えることで あるが，これК加えて，造粒操作の面から，Eq.(10)に よって規制される $L_{(G)}$ の長さの伝熱面禎で，造粒帯で 必要な熱量を与えるとい5条件す満足されなければなら ない。

$$
\begin{aligned}
& \text { すなわち，造粒带での熱收支の式 } \\
& U_{D M r}\left(T_{D(G)}-T_{M(G)}\right) \pi D L_{(G)} \fallingdotseq Q_{w} H_{(G)}
\end{aligned}
$$

から鲚導される $L_{(G)}$ と，Eq. (10) で表示される $L_{(G)}$ とが等しくならなければならない。

Eq.(11) 中, $T_{D(\theta)}$ は造粒带におけるドラム平均温

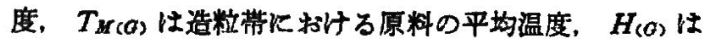


造粒帯に招いて，原料 $k_{\boldsymbol{g}}$ 当たりに必要な熱量を表わす。 一方，UDM はドムから原料への見かけの伝熱俰数》 をあらわすすので，Fig.4亿示すよ5に，ほぼ $T_{D}$ の みの関数々なる。なお $T_{M(G)}$ は，造粒帯では原料が融 出反応状態にあるので, 一定温度となり $U_{D M}\left(T_{D(G)}-\right.$ $T_{M(G)) は} T_{D}$ のみの関数となる。これは造粒帯での熱 負荷に相当する。

いま，Eq.(10)の $L_{(G)}$ と，Eq.(11)の $L_{(G)}$ を等し くおくと,

$$
U_{D M}\left(T_{D(G)}-T_{M(G)}\right)=D \cdot K_{o p t} \cdot H_{(G)} / 4
$$

となり，一定配合率の原料を供給するときは $H_{(G)}$ は一

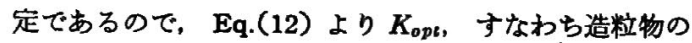
粒径は，TD(G)Kよって規制されることがかかる。

一方，乾燥帯についてみると，その帯域でのドラム平 均温度 $T_{D(D)}$ は，経済的見地より，ドラム材質の許容 限界温度付近で操作することになると考学られるので， 乾燥帯での熱負荷 $U_{D M}\left(T_{D(D)}-T_{M(G)}\right)$ は，造粒操作 とは無関保に，そのドラムの材質により，一定値と淤け る。すなわち

$$
U_{D X}\left(T_{D(D)}-T_{M(D)}\right)=C
$$

とする。

乾燥帯での熱収支は, Eq.(11) と同栏に次式で示され る。

$$
U_{D M}\left(T_{D(D)}-T_{M(D)}\right) \pi D L_{(D)} \fallingdotseq H_{(D)} Q_{w}
$$

$L_{(D)}$ は乾燥带の長さ, $H_{C D)}$ は乾燥带で供給原料 $k_{\boldsymbol{g}}$ 当 たり必要な熱量を表わす。

したがって，乾嬠帯の長さは，上式の関保より

$$
L_{(D)}=H_{(D)} Q_{w} / \pi D C
$$

で表わせる。

いま，上述の $L_{(D)}$ と $L_{(G)}$ との比をとってみると

$$
L_{(D)} / L_{(G)}=H_{(D)} K_{0 p t} D / 4 C
$$

そなり, 造粒物粒径応して, $L_{(D)} / L_{(G)}$ が一定の值に なることがわかる。一方，本装置においては，

$$
L_{(G)}+L_{(D)} \fallingdotseq \text { 加熱部妒長 } L_{(H)}
$$

であるところから，造粒物の粒径に応して， $L_{(G)}$ がー 定に規制されることになる。これらの関係は，Eq.(16), および（17）より，次式で示される。

$$
L_{(G)}=\frac{4 L_{(H)} C}{4 C+H_{(D)} K_{\text {opt }} D}
$$

また一方，ドラム傾斜す Eq. (8) より一定に規制され ることになる。

vii）原料供粭速度 上述のよ5K, 造粒物粒径に

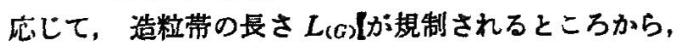
Eq.(9) の関係より，必然的に，その原料供給速度も規 制されることがわかる。

これらの関係は，Eq.(9) 飞上記 Eq.(18) を代入する

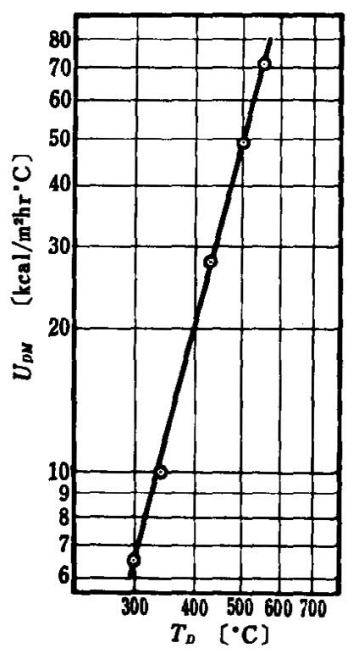

Fig. 4 Relation between drum temperature $T_{D}$ and apparent heat transfer coefficient from drum to material $U_{D M}$

ことにより, 次式のように表わせる。

$$
Q_{w}=\frac{C L_{(H)} \pi D^{2} K_{o p t}}{4 C+H_{(D)} K_{o p t} D}
$$

上式は， $K_{\mathrm{opt}}$ の增加に伴い， $Q_{w}$ が増加する関係にあ る。

実際の操業に拈いて，造粒带での保有率を一定に保ら つつ， $Q_{(w)}$ および云熱量をそれに応して增加させると， $L_{(G)}$ は短かくなり，造粒物の粒径は小さくなる。

\section{結言}

水化物を原料とし，これに加熱操作を加えて行なう連 繶造粒の操作に招いて,

1. Newitt や河野らの，嘲燥粉体に水を添加して行 なら造粒操作に比して，基本的な操作条件では，ほほ同 一の類似関係が成立すること，

2. 造粒物粒徍に応して $\tau, \theta_{(G)}, K, T_{D(G)}, L_{(D)} / L_{(G) \text {, }}$ $L_{(G)}, S, Q_{w}$ らが規制され，結果的に，造粒物粒径に応 して，その生産量が決まること， が判明した。

なお，本実験における造粒水分が，加熱操作が併用さ れるにあかかわらず加熱操作の全く行なわれない河野の 実験のそれにはぼ近似するのは，造粒帯における伝熱の ほとんどか，その帯域での水化物の結晶水融出反応に消 費され，この带域での水分の蒸発は，造粒水分に影響を 与えるほど大きくないためと思われる。 


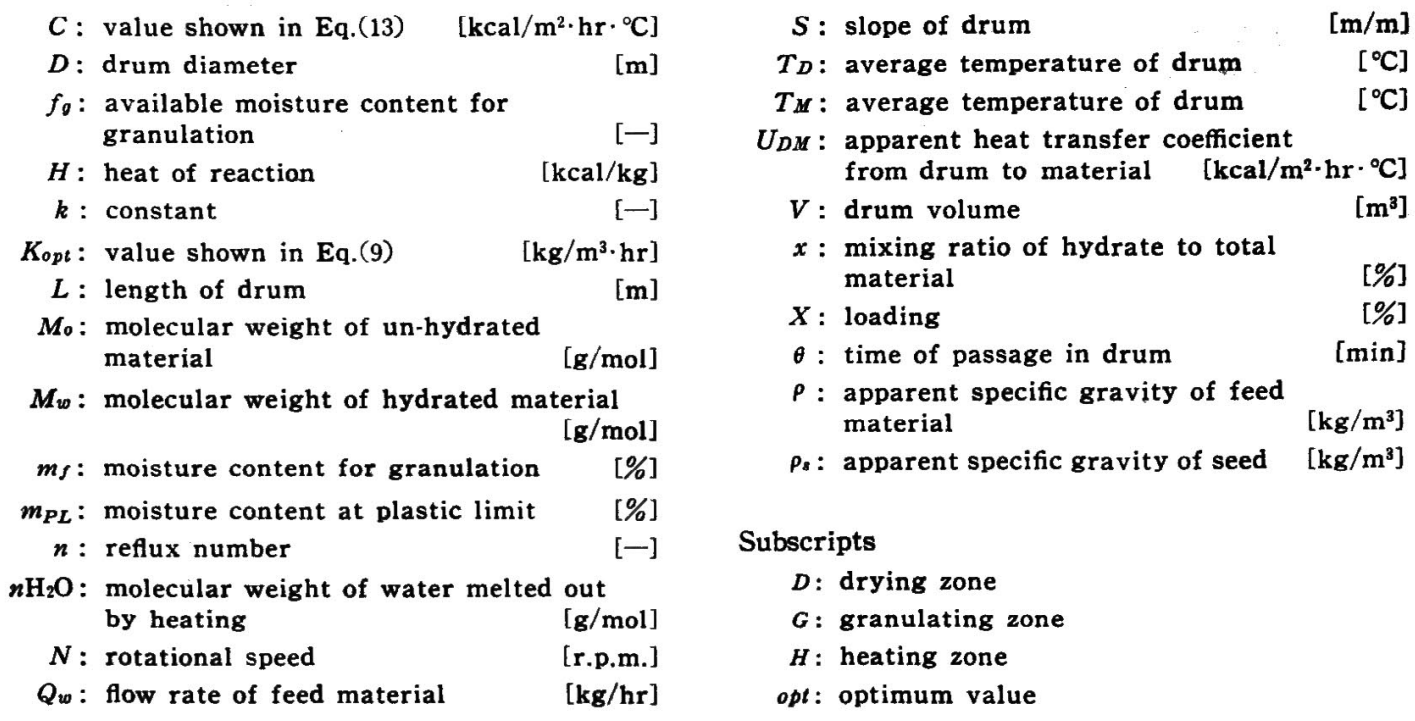

\section{Literature cited}

1) Newitt, D. M., et al. : Trans. Instn. Chem. Engrs., 36, 422 (1958)

2) Kono, H.: Chem. Eng., Japan, No. 3, 1 (1963)
3) Perry, J.H.: Chemical Engineers Handbook, Fouth Edition $20-29$

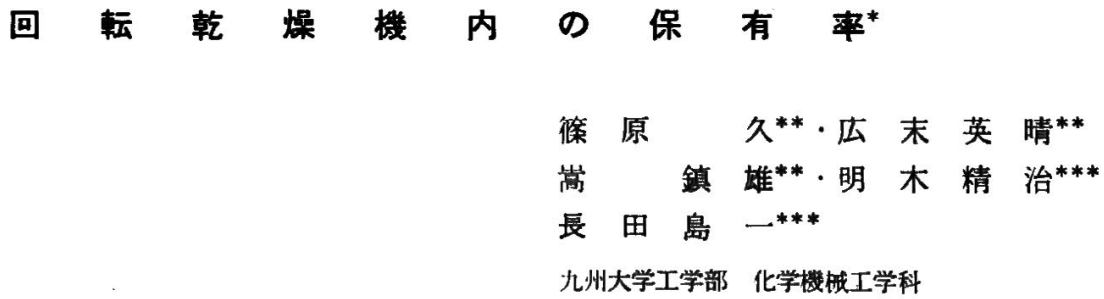

\section{緒}

回転乾燥㙨は処理量が大きいこと、および、運転の安 全かつ容易さのために広く使用され，これに関する研究 論文す多数発表されている。

その主なるのは, 機内における材料の平均通過時間,

- <Hold-up in a Rotary Drier> Received on April 28, 1966 化工協会的西支部九州大会（昭和 39 年 12 月）和よび德山大会 (昭和 40 年 11 月) 飞て洋演発表

** Hisashi Shinohara, Hideharu Hirosue and Shizuo Kasami (Dept. of Chem. Eng., Kyushu Univ., Fukuoka, Japan)

*** Seiji Akegi and Shimaichi Nagata (Ube Industries, Ltd., Ube, Yamaguchi, Japan)
および，その受熱速度に関するすのである。前者につい ては, Friedman $5^{11}$, Prutton $5^{6)}$, Saeman $5^{71}$ に よる各実験式および Schofield ら されているが，いずれるまた完全とはいいがたい。そこ で，著者らは，まず，機内におけける単一球形粒子の理想 的運動を解析し，さらに，摴上板の形拉よび数の差違を 考虑に入れて，無次元整理式の形を予想した。つぎに， これらの式にもとついて実験を行ない，本実験值はるち ろん，既往の文献值をるおおよそ整理できる無次元式を えた。以下にその释過を報告する。 
三成分系の笑液平衡の測定——ソプロピルアルコール水ーイソプロピルエーテル系—（頼㥶正弘・吉村尚真 · 山本武則, 化学工学, 31，451４57 (1967)) 3成分系

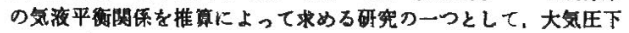
でインプロビルフルコールー水ーイソブロビルエーテル系と、この系

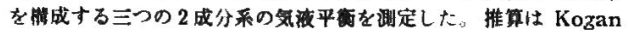
と Margules の方法で竍みたところ、军相檤とよく一致した。

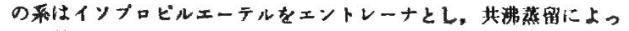

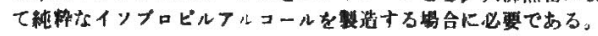

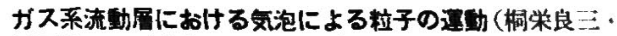
伀野降一辰井良昭，化学工学，31，457４63 (1967))

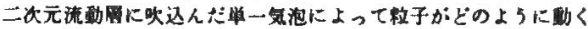

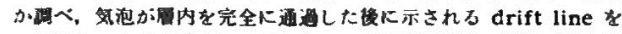

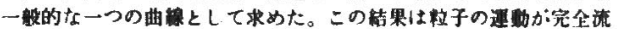

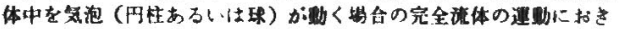
かえられるとし，さらに勧狍中心上り下方，筷泡半佳の的 2 偣の所

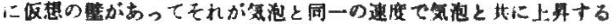
といろモデルKよってかなりよく站明でた。

湿った粒子層における液状水移娌の径路保数(大谷莸盛 . 前田四郎, 化学工学, 31，469４73 (1967)) 湿っ :

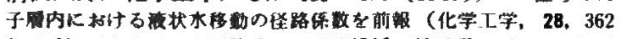

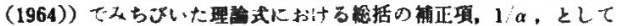

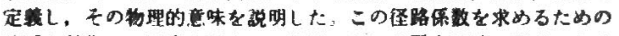

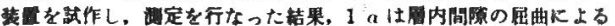

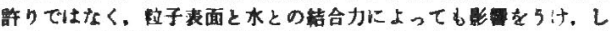

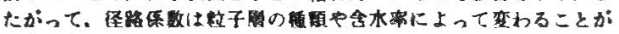
わかった

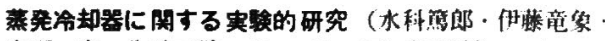
宫下 尚, 化学工学, 31，469 473 (1967)) 本研究纴

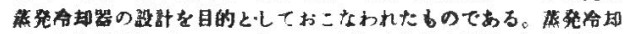

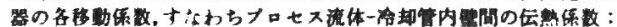

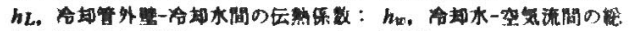

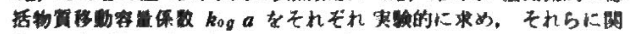

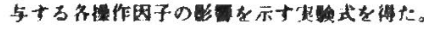

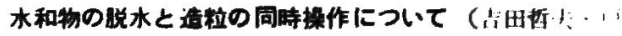
田浩次.山筒尉二, 化学工学, 31, 174 - 478 (1967))

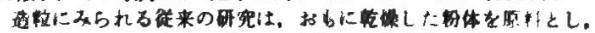

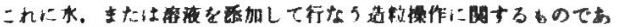

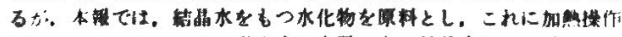

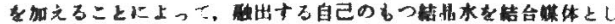

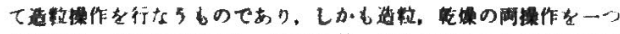

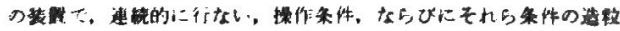
物に改添十影觜を考察した。

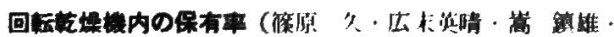

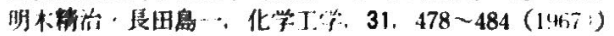

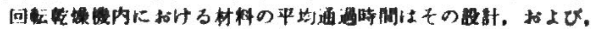

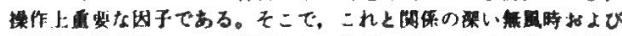

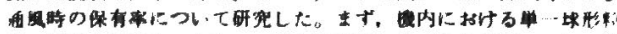

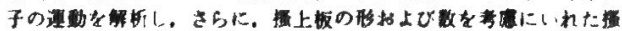

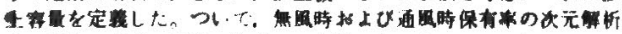

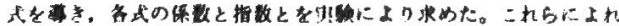

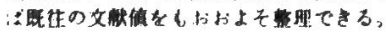

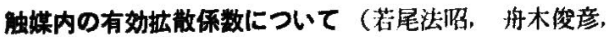
化学工学，31，485～491（1967））本研被は反地系での

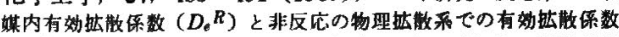
$\left(D_{s}{ }^{D}\right)$ との本页的な相異について検行したるのでるる。蜰媒が広 い細孔分布を有するとき, 反店系で有奻な平均細孔半径上り，非反

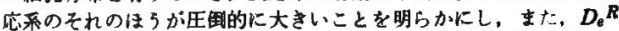

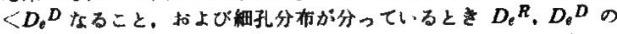

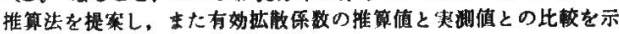
した。

イオン交換における液相拡散に関する解析—等価交換 の場合 一 (片岡 健·前田尚利·佐滕真上·上山惟恒, 化学工学，31，491４97（1967)）等価イオン交換に甜

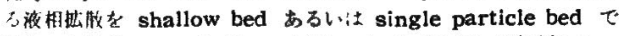
行なった场合について。 Nernst.Planckの式を用いて解析した。

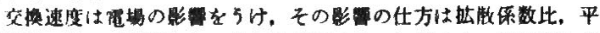

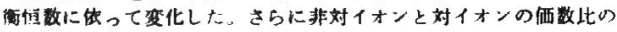
影震を明らかにした。

多孔板抽出段上の連䊺相流体の湿合特性（城塚 正·村上 昭彦, 化学工学。 31，497〜504 (1967)) 段辰 $30 \mathrm{~cm}$ の 多孔板抽出段上の进繶相流体の站合特性をバルステスト法により解 析した。指数阙数を乘じて变形した入出力パルスの平均，分散を用

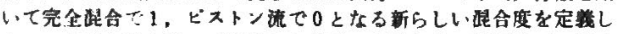

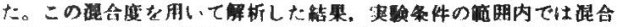

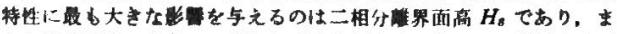

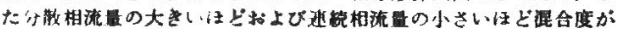

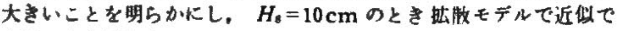
きることを示した。

觧電容至による粉体流量の測定（中島裕头・後藤圭司・ 田中道去，化学工学，31，504～507 (1967)) 粉体 7口

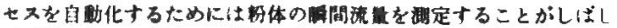
ば必要となる。徒来この湖通に閣して2，3の方法か提案されてい

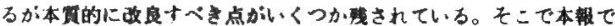

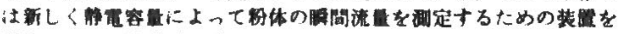

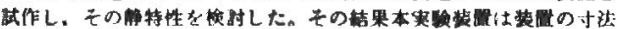

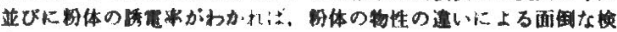

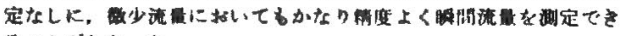
ることがかった。

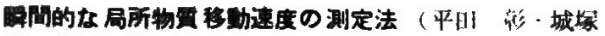

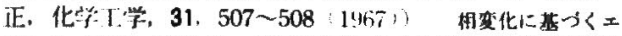

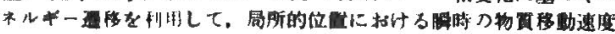

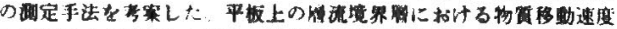

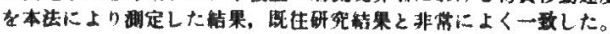

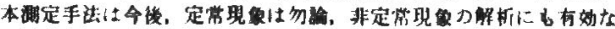
厅段として通用でるいのと考えられる。

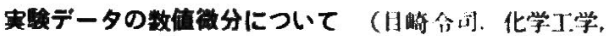

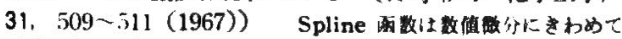

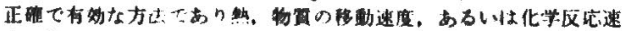

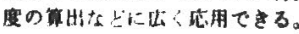

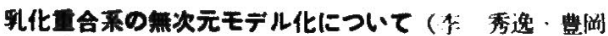
豊. 叔本立也, 化学工学, 31, 511 -512 (1967)) Har

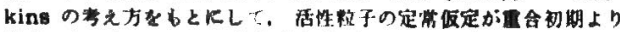

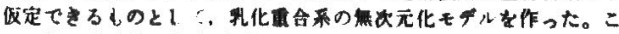

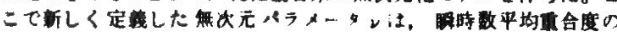

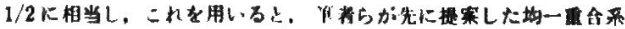
の "עヒデ"と形式的に一政する。 